\title{
Ethnographic Approaches to Race, Genetics and Genealogy
}

\author{
Katherine Tyler*
}

\begin{abstract}
In recent years, there has been a technological advance and commercial boom in genetic technologies and projects, including a renewed scientific interest in the biological status and genetic constitution of race. This article provides an overview of sociological approaches to the study of race and genetics, and argues that these analyses should pay detailed critical attention to laypeople's engagements with the new genetic technologies. Drawing upon growing bodies of ethnographic literature within anthropology, geography and sociology, this paper unravels the complex and ambivalent ways in which laypeople think about the biological and genetic constitution of racial identities. Two specific bodies of literature are examined. First, the new kinship studies within anthropology that explores laypeople's engagements with the new reproductive technologies, such as in vitro fertilization. Second, laypeople's uses of genealogical technologies that claim to trace family ancestries, including racial descent and ethnic origins.
\end{abstract}

Over the last 20 years there has been a technological advance and commercial boom in genetic technologies and projects. These developments include a renewed scientific interest in the biological status and genetic constitution of race. This aspect of genetic research is of interest to sociologists and others working in the field of race and ethnicity studies. The consensus among sociologists is that race is a social construction with no biological foundations. Indeed, to emphasize this point, many sociologists write the term 'race' in scare quotes. Yet, sociologists and others continue to document the significance of assumptions and practices founded upon a belief in the existence of race and races.

The meaning of race and the ways in which it defines population groups and individuals as 'self' and 'other' is historically and geographically contingent and so is open to transformation over time and across space (Goldberg 1993). It is precisely the adaptive capacity of the concept of race that allows it to assign to population groups ideas of humanity, similarity and difference. While accepting that the idea of race is historically contingent, there is a general acceptance by sociologists and anthropologists that ideas of racial difference draw upon notions of phenotype, hereditary, nature and culture (see Bulmer and Solomos 1999; Wade 2002 for overviews of the history of race).

The 18th and 19th centuries have been identified by scholars as a period of scientific racism, whereby physical differences such as skin colour, hair type and body shape were taken as markers of absolute biological differences giving weight to the idea that one race was biologically superior to other racial groups. After the Second World War, sociologists identified a 'new racism' (Barker 1981), whereby cultural differences, such as food, family formation, language, religion and so on were thought to create distinctions between so-called races (Gilroy 1987; Wetherell and Potter 1992). Many writers insist that the idea of racial differentiation, even if expressed in cultural terms, implies a commitment to the idea of biological distinction rooted and fixed in nature (Goldberg 1999). In other words, the post World War language of culture was often mobilised to construct and represent innate properties of groups akin to biological differences (Malik 1996). In short, the social construction of race and racism oscillates between 'the warring domains of Culture and Nature' 
(Gilroy 1997, 331) and in so doing discourses of culture and biology continue to work in complex and strategic ways to exclude people on ethnic and racial grounds (Hall 2003).

In this essay, I shall examine sociological analyses of the most recent innovations in the science of race and genetics, and its impact on the social construction of race. My starting point is the division amongst sociologists over the political and social implications of the advance in scientific research on race and genetics. Most sociologists tend to take a 'dystopian' (Skinner 2006) standpoint to argue that genetic science will lead to the revival of scientific racism at the popular level. In other words, it seems to me that most sociologists propose that research on race and genetics reinforces deterministic narratives and ideas of biological difference associated with eugenics and the Holocaust. From this standpoint, any science of race and genetics is thought to be by definition wrong in supporting the idea that innate biological differences exist that separate and define racial groups. By contrast, some other sociologists take a more optimistic and 'utopian' (Skinner 2006) point of view to contend that genetic science will abolish racial thinking forever. In this sense, it is argued that the science of race and genetics disproves the biological existence of racial differences and thus opens the way to an anti-racist and post-race future. While I whole-heartedly support and agree with the argument that race is a social construction, I depart from those sociologists that tend to evaluate the social and political implications of research in the field of race and genetics as either utopian or dystopian in its consequences and effects. In this paper, I shall argue that this dichotomous thesis is too simplistic. To do this, I shall scrutinise a body of ethnographic scholarship that explores how laypeople, who are not scientists, engage with the new genetic technologies. This body of literature examines laypeople's engagement with the new genetic technologies and their ideas on the biological and social constitution of race. In the course of so doing, these ethnographic studies shift the focus of the sociological debate away from the study of scientists' work on genetics to the thoughts and reflections of laypeople. It seems to me that sociologists can not afford to ignore laypeople's engagements with the new genetic technologies. This is because it is precisely within the everyday life-worlds of laypeople that the social consequences of innovations in the field of race and genetic science is experienced and realised. Moreover, given that the majority of sociologists understand the idea of race to be a social construction, it is imperative that detailed critical attention is given to the slipperiness and complexities of the actual processes of that construction in everyday beliefs and practices.

Having set the scene for what is to follow, I shall now turn to a detailed exploration of both sides of the sociological debate on the social and political implications of research on race and genetics.

\section{The two sides of the race debate: Dystopian and utopian perspectives}

Thinking of the potentially progressive and positive implications of genetic science for the social significance of 'race', Paul Gilroy $(2000,32-6)$ advocates that the 'nano-scale' of genetic technologies that 'operate beneath the surface of the skin' signals the end of racial classification grounded upon visual physical differences, such as skin tone, and cultural essentialisms, such as religion. In this vein, it is becoming increasingly commonplace for sociologists within the broad field of race and ethnicity studies to make passing and often brief references to the arguments put forward by those geneticists that support the idea that race has no biological foundation. For example, Parker and Song $(2001,4)$ note in the introduction to their edited collection 
of essays on the formation of mixed-race identities that 'the emerging scientific orthodoxy credits modern genetics with undermining the ontological status of "races" '. In a similar vein, the 1998 American Anthropological Association (AAA) statement on the meaning of race drew upon scientific evidence to argue that "that human beings are not unambiguously, clearly demarcated, biologically distinct groups' (AAA statement on race, cited in Ifekwunigwe 2004, 97). This claim is rooted in the idea that 'there is greater variation within "racial" groups than between them' (AAA statement on race, cited in Ifekwunigwe 2004, 97). This is accounted for and explained by the historical displacement and migration of people across the globe, and the fact that the members of human groupings have always had sex with each other. In this sense, population geneticists have suggested that racial and ethnic divisions are social categories that are assigned to biologically diverse groups of people. For example, the geneticists Cooper et al. (2003) have recently argued in the New England Journal of Medical Research, 'there is no evidence that the units of interest for medical genetics correspond to what we call race'. Similarly, Francis Collins, Director of the Human Genome Project, is famous for advocating that the 'separation of the human population into precisely defined racial categories is scientifically unjustifiable' (cited in Conduit et al. 2002, 375; for a fuller account of this line of argument, see also Wade 2007b).

While some sociologists, and anthropologists, have drawn upon this science of race and genetics to illustrate that the idea of race is a social construction, my survey of the sociological literature leads me to conclude that most sociologists tend to take a more pessimistic point of view. In this sense, most sociological commentators focus on the ways in which the science of race and genetics supports biological and deterministic accounts of racial difference. To these sociologists' eyes, it is thought that any discussion of biology in relation to human populations and groupings inevitably results in a racist science (Skinner 2007). In short, these sociologists propose that the science of race and genetics is intimately connected with earlier manifestations of scientific racism and thus reproduces biologically determined models of race (see, e.g., Duster 2003; Kay 1993; Nelkin and Lindee 1995; Rothman 1998). As Skinner $(2006,469)$ comments, 'Dystopians see signs of a future in which "polite" forms of eugenics reappear ...'. It is precisely from this point of view that some sociologists have deconstructed population geneticists' and molecular biologists' lectures, speeches, books and documentaries on the diversity of population groups, to question and challenge the ways in which such accounts unintentionally reformulate biologically determined accounts of race, ethnicity and nation (Gannett 2001; Steinberg 2000). Geneticists are also critiqued by some sociologists for making links between the inheritance of specific diseases and racial origin (Duster 2002, 2003). In addition, dystopians fear that scientific inquiry that attempts to find a genetic basis for addiction and intelligence will further forms of racism and victimisation of black and ethnic minorities (see Skinner 2006 for examples). This concern is most obviously realised in developments in the use of DNA to test for the ethnicity of crime suspects (Lowe et al. 2001; Shiver et al. 1997). Furthermore, some sociologists have critiqued the Human Genome Diversity Project that set out to map genetic diversity across the globe for mistakenly associating genetic homogeneity with indigenous peoples (e.g., see Reardon 2001). It was argued that this model of racial difference reformulated colonial notions of racial hierarchies to place indigenous people in a relationship of evolutionary inferiority to the West. In sum, then, those sociologists that take a dystopian perspective on developments in the field of race and genetic science conclude that molecular genetics, behavioural genetics and 
sociobiology provide a language and set of ideas that reproduce the idea of the geographically bounded and biologically determined constitution of racial, ethnic and national groups. Thus, the argument is that the potentially anti-racist implications of scientific findings that claim to undermine the biological status of race are open to abuse by racist groups, as well as politicians, doctors, the police, the general public and even scientists themselves.

It seems to me that this sociological debate usefully illuminates the profound social, political, ethical and moral significance of recent scientific research on genetics for the social construction of race. Clearly, there is much at stake for the whole of humanity. However, I am deeply concerned by the way in which this debate at times constructs utopian and dystopian perspectives as mutually exclusive. In this sense, geneticists are sometimes presented as either anti-racist angels, in refuting the biological existence of race, or racist devils for supporting that construction. In my opinion, this leaves social scientists feeling wrongly obliged to position themselves in either the utopian or dystopian camp. A further consequence of framing this debate in this way is to leave some sociologists reluctant to engage in discussions on race, genetics and biology for fear that such talk will ultimately support and reformulate biologically essentialist ideas of racial difference (Skinner 2007; Tyler forthcoming).

Moreover, this is to ignore the growing plethora of ethnographic evidence that unravels and analyses laypeople's engagements with the new genetic technologies. This ethnographic level of analysis productively shifts the focus of sociological attention away from what scientists say about the biological constitution of race to laypeople's thoughts and reflections on these issues. In so doing, these ethnographies begin the critical and necessary work of deconstructing laypeople's ideas on race and biology, as well as illustrating how the new genetic technologies are shaping everyday life. It seems to me that given the ontological truth that race is a social construction, sociologists can not ignore the everyday and mundane ways in which laypeople imagine the biological and genetic construction of race. Significantly, for the argument that I shall advocate and develop in this paper, these ethnographic studies illuminate how laypeople's discourses on race, biology and genetics work in much more complex and ambivalent ways than that allowed for by the arguments proposed by either the utopians or dystopians when they think of the social impact of research in race and genetics.

In what follows, I shall review some of this ethnographic literature. In the course of so doing, my focus will be on work within anthropology, geography and sociology that explores laypeople's engagements with innovations in the new science of race, biology and genetics. My argument is that this body of literature reveals how lay discourses on race work in ambivalent ways to both reinforce and challenge ideas about the biologically fixed constitution of racial differences and identities. In this way, laypeople's engagements with innovations in the science of race and genetics do not straightforwardly reproduce and reformulate biologically essentialist ideas of racial difference. In fact, some ethnographic studies show how genetic science has offered possibilities for individuals and communities to imaginatively reshape and redefine ideas of racial and ethnic identity and belonging. Similar lines of argument have also been developed and proposed by Peter Wade (2002; 2007b) and David Skinner (2006). This paper has been heavily influenced by these writers' work and though on this matter. To illustrate this argument, I shall discuss two bodies of literature: the first is known as the 'new kinship studies', which is a body of anthropological writing that examines laypeople's engagements with the new reproductive technologies (NRTs), such as in vitro fertilisation (IVF; 'test-tube' 
babies), ova and sperm donation. The second body of literature that I shall analyse explores how laypeople appropriate and mobilise the new genealogical technologies that have been developed by population geneticists to trace collective group ancestries and family histories. While there is a growing literature that examines the mobilisation of the new reproductive technologies by people living outside of the West (Clarke 2008; Inhorn 2003; Kahn 2000; Simpson 2004), in this paper, I shall focus my discussion on examples drawn from the United Kingdom and the United States.

\section{Kinship studies and the new reproductive technologies}

Social anthropologists are experts when it comes to the study of kinship. For decades, cultural and social anthropologists on both sides of the Atlantic have debated the relationship between the biological (what is thought to be given at birth) and the social (what is said to be passed on through upbringing) in the formation of Western and non-Western 'cultures of relatedness' (Carsten 2000). Advances in the new reproductive technologies have offered feminist anthropologists the opportunity to scrutinise how everyday understandings of social and biological relatedness mediate discourses on the meanings of motherhood and fatherhood. For example, conception assisted by these techniques might include three women: a woman who donates the ova (egg) to be fertilised, a surrogate mother who gestates the foetus and gives birth to the baby, and a further woman who brings up the child. Moreover, these techniques make it possible for the biological father (sperm donor) to be separate from the social father (Snowden and Snowden 1993).

Some anthropologists have studied the diverse ways in which these relationships are explained, configured and understood by those involved in these procedures, such as doctors, clinicians, donors, surrogates and parents-to-be (Franklin 1997; Franklin and McKinnon 2001; Ragoné 1994; Ragoné and Twine 2000). Anthropologists have also explored how gay and lesbian families deploy these technologies (Hayden 1995; Weston 1991). Others have focussed on the social, ethical and legal implications of such techniques, and the ways in which they are discussed and debated in the media, the law and by politicians (Edwards et al. 1999; Franklin and Lock 2003; Strathern 1992, 2005). A further strand of this literature explores how lay observers, who have no vested interest in NRTs, draw on their own cultural and political worldviews to reflect upon the social and ethical implications of these biotechnologies (Edwards 1999, 2000, 2005; Edwards and Salazar 2008). The supposition that cuts across this work and thought is the contention that NRTs challenge preconceptions about the biological facts of reproduction and the significance of these facts for Western kinship systems. For a long time, it has been thought by anthropologists that the biological relationship between a man, a woman and their offspring provides the universal base-line for European and American kinship, upon which social relationships and cultural meanings are built (Schneider 1980). In short, anthropologists have traditionally advocated that within Western kinship 'blood is thicker than water'. However, the boom in the new reproductive technologies towards the end of the 20th century has enabled anthropologists to explore the imaginative configuration of the biological and the social in Western ideas of kinship, identity and personhood.

\section{Race, genetics and gestation}

It is against this background that some anthropologists have paid detailed critical attention to how mothers-to-be, surrogates, sperm donors and adoptive parents think 
about reproduction and kinship in ethnic and racial terms (Hartouni 1997; Howell and Marre 2006; Ragonè 1998, 2000; Thompson 2001; Wade 2002, 2007b; Wiegman 2003). These scholars unravel and analyse the thoughtful, strategic and imaginative ways in which laypeople articulate notions of racial difference and sameness, biological and cultural relatedness to reflect upon the meaning of parenthood and personhood. In the course of so doing, my contention is that these studies highlight the paucity and inadequacy of both the utopian and dystopian frameworks advocated by some sociologists to think through the social significance and meaning of innovations in the science of race and genetics. In short, the alacrity with which some laypeople mobilise and articulate ideas of race, biology and genes when they engage with NRTs illustrates how lay accounts of race and biology neither simply support, nor undermine biologically deterministic models of racial difference.

The details of my argument are revealed in ethnographic studies that scrutinise the choices of gestational surrogate mothers, women who are not genetically related to the foetus that they are contracted to carry for people that will become the social parents of the child. Heléna Ragoné's work draws on extensive interviews with commercial surrogate mothers in the United States $(1998,2000)$. She reports that it is not unusual for gestational surrogates to choose to carry a baby for couples of a different ethnic and racial identity to themselves. Reflecting on this decision, Ragoné contends that these women used the idea of race as a 'distancing device' to create an emotional disconnection and separation between themselves and the baby $(1998,126)$. In contrast to the women with whom Ragonè worked, Hartouni $(1997,85-98)$ explores the details of an African-American gestational surrogate's custody battle for a baby that she was contracted to carry for a white couple. The black woman claimed that the process of gestation had led her to develop 'more feelings' for the baby than the child's 'natural parents' could have $(1997,85)$. Thus, unlike the women in Ragoné's study, this surrogate felt that the biological process of gestation facilitated a feeling of multicultural kinship between herself and the child in the absence of racial affiliation and genetic relatedness.

These examples illuminate the contextual, changing and shifting emphasis that laypeople give to ideas of shared racial identity, biological and genetic relatedness in the making of kinship. While Hartouni argues that the process of gestation created a feeling of multicultural kinship, for the women with whom Ragoné worked, the absence of genetic and racial relatedness was thought to guard against the development of such feelings. My argument here is that the contrasting and creative ways in which these women mobilise ideas of biological, genetic and racial relatedness belies the argument that the discussion of genetics, race and biology simply reformulates or undermines a biological account of race.

\section{The birth of black twins to a white IVF mother}

My own work builds upon this argument to examine laypeople's understandings of the role of gestation, biology and genetics in conferring racial affiliation and distance between mother and child in Britain (Tyler 2007). The focus of my study was the British press and public's reactions to the accidental mixing of a black and a white couple's gametes undergoing IVF in the same clinic. This incident erupted into a national media event whereby the press speculated on whether the black couple's fertilised egg was wrongly implanted into the white woman or the black man's sperm was used to fertilise the white woman's egg. The question posed by the media was 'Who are the real parents of the twins?' (Kay 2002). 
At the time of this story broke, I was beginning 12 months of ethnographic research that set out to explore laypeople's understandings of innovations in the field of race and genetics (Tyler 2005, forthcoming). My fieldwork was situated in an ethnically diverse neighbourhood of a British city. As part of this fieldwork, I asked residents of this locality, across racial, ethnic, religious, class and gendered locations, what they thought to the birth of the black twins to the white IVF mother. My coconversationalists' reactions to this event illuminates the contradictory ways in which laypeople's understandings of race, genes and biology traffic between an essentialist racialised discourse that reaffirms naturalised and bounded notions of race and ethnicity, and a more progressive discourse that undermines the black:white binary. In this sense, my co-conversationalists' accounts shed further light on the ways in which lay accounts of race and biology neither reinforce nor undermine biological discourses on race. Rather, my interpretation shows how utopian and dystopian perspectives on race, genetics and biology are not easily disentangled into an eitheror point of view. From one perspective, it could be argued that my coconversationalists' ideas on the biological constitution of race signals a return to nineteenth century race science; yet, at the same time, their views could also be interpreted to signal a post-race future that points towards the end of the concept of race.

To illustrate this argument, let us consider my co-conversationalists' view that the white couple could be the genetic parents of the black twins. In this regard, some interviewees mobilised the idiom and idea of 'throwback' to explain this mistake (Tyler 2007, 43-5). They proposed that physical traits associated with racial identity, such as skin colour, inherited in previous generations could unexpectedly reappear in the present. On the one hand, the idea of 'throwback' points to the ways in which an individual's racial identity is not fixed. From this point of view, children need not resemble their genetic parents in terms of physical characteristics associated with race. Moreover, the notion of 'throwback' could be said to share parallels with population geneticists' understanding that people from different racial groups are to some extent interrelated. However, it might also be the case that the idiom of 'throwback' suggests the idea that racial characteristics can lie dormant in the body to reappear in unpredictable and shocking ways in later generations. In this sense, it could be argued that my co-conversationalists' ideas are akin to 19th century theories of racial inheritance, in particular a theory called 'telegony'.

Peter Wade (2002, 94-6) reports that the theory of telegony proposes that a man who has a child with a woman can influence the offspring that the woman has with further men. Interestingly, for my understanding of my co-conversationalists' ideas, Wade (2002) illuminates the persistence of racialised versions of this theory in the 20th century. To do this, he draws upon an empirical study conducted in the 1970s with older white women from Bristol, a city situated in the South West of England. Some of the women in the Bristol study suggested that if a white woman had sexual intercourse with a black man, she might bear children 'tinged' with blackness, even if the father is white. In contrast to these older white women, the people with whom I worked did not perceive the birth of black children to a white couple be a necessarily negative occurrence. Nor did they place the same emphasis upon the immediate, intergenerational and gendered aspects of inheritance. Nevertheless, it could be argued that my co-conversationalists' emphasis upon the persistence of racial traits across generations indicates the resonance between the theory of telegony and the ways in which they think about the inheritance of the racialised body. 
Before moving onto the next section, it is worth taking stock of the arguments presented so far. In this section, I have explored gestational surrogates' and laypeople's engagements with the new reproductive technologies. In the course of so doing, I have proposed that reflecting upon everyday engagements with these technologies can enable the critical work of exploring laypeople's ideas of racial, biological and genetic relatedness. My contention is that this ethnographic level of analysis does not straightforwardly concur with those sociologists that contend that the genetic technologies facilitate the overcoming of the idea of race. Nor do these ethnographic examples simply suggest that discourses of biology, genes and race are put to work to reproduce exclusive communities of racial ancestry and descent. Rather, the new kinship studies within anthropology 'denaturalises kinship as a universal category' (Nash 2002, 30), and in so doing illuminates how laypeople's understandings of biology, genes and race are mobilised in slippery, contradictory, ambiguous and unpredictable ways.

\section{Ancestral research and genealogical identities}

I shall now explore how ideas of biological and genetic relatedness are played out in laypeople's engagements with advances in genealogical technologies that are designed to trace ancestral origins and identities (Wade 2007b). According to some geneticists, innovations in genetic science mean that the DNA contained in a swab of saliva can provide information on the genetic identities of forgotten ancestors. Over the last decade or so, there has been a proliferation of books, websites, commercial companies and television documentaries that have marketed these advances in population genetics to laypeople interested in tracing their family trees (BBC Motherland: A Genetic Journey 2003; Bodmer and McKie 1995; Horizon Sir Walter's Journey 1994; Sykes and Irven 2000; Sykes 2001). While some geneticists question the personal and individual value of this information, the popular appeal of these technologies in Europe and the United States reflect the Western fascination with the past, heritage, family and oral histories (Brodwin 2004; Nash 2002; Tutton 2004). From this point of view, the commodification and consumption of genealogical technologies means that 'the globalised rhetoric of technoscience meets the intimacy of personal genealogies, identities and family relatedness' (Nash 2004, 2). Although population geneticists are acutely aware of the charge of racism and misgivings about the historical link between human genetics and eugenics, anthropologists and cultural geographers argue that some such studies add weight and certainty to the idea of the existence of genetically homogeneous ethnic and racial identities. This is not surprising given that the focus of analysis is 'genetic kinship' of population groups to the exclusion of social relationships (Nash 2004).

In spite of this critique, sociologists have as yet given little critical attention to the appropriation and use of these technologies by laypeople interested in tracing their family histories. Thus, there is a dearth of sociological work that scrutinises the impact of genealogical technologies on laypeople's understandings of their racial and ethnic identities. However, the few studies that have examined these issues add complexity to the utopian and dystopian futures advocated by some sociologists when they think of the implications of genetic research on the social and biological significance of race. In this way, those few scholars that have examined laypeople's use of genealogical technologies to trace their family trees, share parallels with anthropological accounts of laypeople's engagements with NRTs. In this sense, these studies challenge the argument that the search for genetic roots and origins necessarily signals a return to the idea of absolute and essential racial and ethnic biogenetic 
identities. Moreover, studies of laypeople's engagements with the new genealogical technologies complicate the idea that the quest to know 'who you are' and 'where you come from' straightforwardly undermines the notion of discrete biological racial ancestries. The complexities of this approach is summed up by Catherine Nash (2002, 49 ) in the conclusion to her study of Americans', Canadians' and New Zealanders' searches for their Irish ancestries. Nash $(2002,49)$ writes as follows:

Genealogy, despite its easy co-option in essentialist versions of identity, may provide a way of beginning the task of understanding the complexities of subjectivity and social location, and of rethinking identity as neither eternally fixed and essential, nor endlessly fluid and freely self-fashioned, as an always incomplete inventory of the self.

Nash's conclusions are based on her research with people using traditional methods to trace their family trees such as archival research. In the following sections, I shall illustrate how this analysis of the constitution of genealogical identities is equally applicable to those people that deploy the new genealogical technologies to find out 'where they come from'. The first example that I shall draw on explores laypeople's thoughts on their participation in a scientific experiment that looked for 'the original Britons'; and the second example analyses how African Americans have deployed advances in population genetics that claim to trace and identify lost African ancestries.

The search for 'the original Britons'

The distinguished population geneticist Sir Walter Bodmer recently wrote and presented a television documentary that set out to discover the original Britons (Cross 2001; Tutton 2004). While Bodmer was keen to stress throughout the programme that the original Britons could not be identified in racial terms, it became apparent as his search progressed that he implicitly thought of them as white in terms of racial and ethnic identity. Indeed, Bodmer proposed that the indigenous people of Orkney, a remote Island off the coast of Scotland, were the original Britons. He advocated that the Island's geographic isolation and relative lack of immigration facilitated the maintenance and control of a pure line of descent to ancient Norse ancestors. One consequence of this discourse was for whiteness to guarantee 'genetic proximity to an ancient British population' (Cross 2001, 427). In this way, the ancestries and origins of Asian, black and other non-white Britons were positioned elsewhere and thus outside of the United Kingdom (see also Nash 2004, 26).

Richard Tutton $(2002,2004)$, a sociologist, interviewed some of the Orkney Islanders who participated in Bodmer's study. Although Bodmer in his film portrayed his research participants as 'wanting to know where they came from', Tutton (2004) found that the people he interviewed had more elaborate and diverse reasons for participating in the research. According to Tutton (2004), most Islanders were interested in receiving personal information on their family's history. Some people also sought verification of specific ancestors, knowledge of whom was passed on orally within families and across generations. In this sense, the people that Tutton interviewed were not interested in tracing their community's collective Viking identity. Rather, they were intrigued by finding out about family ancestries that spanned the United Kingdom and the globe. Thus, while Bodmer understood genealogy as a tool to anchor collective community origins rooted in genetic kinship, for the people of Orkney genetic information was only meaningful when combined with personal knowledge and family history. By contrast to Bodmer's concern to 
pinpoint a single origin and ancestral trajectory for this community, Orkney Islanders understood their personal, family, community, national and ethnic identities as hybrid and heterogeneous. This example points towards the contrasts and complexities between fixed versions of belonging mobilised by some population geneticists, and the more flexible approaches to ancestral identity taken by some family genealogists. It is precisely this contrast that is played out in accounts of laypeople's search for forgotten slave ancestries.

\section{Slave histories and genealogical ancestries}

Central to innovations in geneticised genealogy has been the promise by some population geneticists that these techniques hold the potential to trace and locate forgotten slave ancestors (e.g., the BBC documentary Motherland: a Genetic Journey). However, this is not a new story because there is much sociological work within the United States that discusses how oral and archival histories of slavery have shaped individual and family identities (Gates and Higginbotham 2004; Gatson 2003; Hall 1998; Parham 2008; Waters 1990). These studies show that the use of traditional archival research methods into family histories hold the potential to challenge ideas of homogeneous racial ancestry within seemingly 'just' black or 'just' white families. That is, the discovery of slave ancestries often illuminates forgotten interracial European and African ancestries. A famous and inspirational example of this practice for many African Americans is Alex Haley's (1976) promise in his epic novel Roots that the geographically dispersed descendents of African slaves could, through archival research, trace their genealogical 'origins' to Africa. Reflecting upon Haley's novel, the population geneticist, Steve Jones argued that the new genealogical technologies would have saved Haley his trip to Africa.

The anthropologist Paul Brodwin (2004) acknowledges that at first glance this genealogical science appears to represent an affront to the cultural and antiessentialist paradigms of identity dominant in the academy that favour ideas of rootlessness over the search for fixed genetic roots. Instead of simply endorsing this orthodox position, Brodwin contends that anthropologists must pay detailed critical attention to the personal, social and political mobilisation of genetic information by laypeople. He argues that African Americans have drawn upon genetic information to inform their historical and political consciousness of Atlantic slavery and its impact upon the present. Such techniques have enabled the descendants of slaves to trace their ancestries to Africa, and also reveal their racially 'mixed' genealogies that are the result of centuries of white sexual exploitation and rape of Africans. In these ways, Brodwin $(2004,119)$ argues that the idea of 'science as a guarantor of truth' and 'genes as stable over time' has come to prove a vital 'step in helping heal the historical wounds of slavery'.

Read collectively, the studies discussed in this section highlight some of the ways in which family genealogists are mobilising genetic knowledge of forgotten ancestors. It is precisely the subtle ways in which ideas of genetic ancestral connections are deployed in these accounts that makes me question the validity and usefulness of the utopian and dystopian framework advocated by some sociologists to interpret the race debate on genetics. That is, in contrast to these arguments for the proposition that genetic science either supports or challenges biologically essentialist models of racial difference, this ethnographic evidence unravels how knowledge of genetic ancestries can inform laypeople's engagements with difficult questions of racial identity and belonging. In this way, knowledge of genetic kinship and ancestry can be put to work to undermine the idea of racially pure descent within families. And 
yet at the same time, such knowledge can become part of a wider political project that explores the role and significance of slavery in the formation of collective diasporic black identities.

\section{Conclusion: Troubling dystopian and utopian perspectives}

\section{DNA Pioneer James Watson is Blacker Than He Thought}

JAMES WATSON, the DNA pioneer who claimed Africans are less intelligent than whites, has been found to have 16 times more genes of black origin than the average white European. An analysis of his genome shows that $16 \%$ of his genes are likely to have come from a black ancestor of African descent.

\section{The Sunday Times}

9 December 2007 Jonathan Leake

I conclude with this extract from a newspaper article about James Watson, who worked out the structure of DNA in 1953, because I think it nicely illustrates how innovations in genetic science hold the potential to realise simultaneously both utopian and dystopian racial futures. From a dystopian perspective, the renewed scientific interest in race and genetics has opened up the space for scientists like Watson to propose the deeply racist and insane idea that black African people are less intelligent than white Westerners. However, from a utopian point of view, these technologies suggest that Watson is himself of African descent. Thus, it would seem that the science of race and genetics holds the potential to simultaneously undermine and support the idea of the existence of discrete biological racial categories and groups. In this way, this short extract illustrates the simplicity of mobilising either a utopian or a dystopian framework to interpret the social implications of research in race and genetics.

It is precisely detailed critical attention to the often ambivalent articulation of ideas of race and biology at the popular level that I think should lie at the heart of the sociological study of race and genetic science. It seems to me that too many sociologists tend to constrain their discussions of innovations in race and genetics to an analysis of scientists' work and thought on this matter. While other sociologists have been wary of even engaging in such debates for fear that any discussion of race and genetics will inevitably support biologically determined ideas of racial difference. Given that most sociologists would agree with me that race is a social construction, it seems imperative that we take seriously laypeople's reflections on how ideas of biology and genetics mediate that construction.

\section{Acknowledgements}

I became familiar with the literature discussed in this paper through my participation in a project entitled 'Public Understandings of Genetics: a cross-cultural and ethnographic study of the "the new genetics" and social identity". European Commission Fifth Framework Programme: Quality of Life and Management of Living Resources. Contract number: QLG7CT-2001-01668.

http://les1.man.ac.uk/sa/pug/. I am very grateful to the members of the project consortium for helping me to think about these ideas. In particular, I would like to thank Peter Wade, my mentor on the project, and Jeanette Edwards, the project director, for teaching me how to think anthropologically about innovations in the field of race and genetic science. I am grateful to the three anonymous referees and David Brunsma of Sociology Compass for their detailed, considered and very helpful feedback. Thanks also to Nigel Pleasants whose perceptive comments on a draft of this paper have helped me to sharpen up its arguments. 


\section{Short Biography}

Tyler's research has examined the formation of White ethnic identities with particular reference to the ways in which Englishness/Britishness is portrayed as essentially White, suburban/rural and middle-class. Her research has also explored ideas of genealogy, ethnicity and identity with particular attention given to how the members of interracial families think about ideas of belonging, descent, inheritance and ancestry across racial, ethnic, religious and classed lines. Tyler has recently conducted research on collective action, ethnicity and the state. She has published her research in these areas in the following journals: Ethnos, Ethnic and Racial Studies, the Sociological Review, Identities: Issues in Global Culture and Power. Tyler has also contributed to several edited collections and is co-editor of Majority Cultures and the Everyday Politics of Ethnic Difference: Whose House is This? (Palgrave Macmillan 2008). She is now working on a monograph entitled Decolonising Whiteness (Palgrave Macmillan 2010). Before coming to the Department of Sociology at the University of Surrey where she holds the post of Lecturer in 'race' and ethnicity, Tyler was a Research Fellow in the Department of Social Anthropology at the University of Manchester, where she also studied for her $\mathrm{PhD}$ and undergraduate degrees in Social Anthropology.

\section{Note}

* Correspondence address: Lecturer in Race and Ethnicity, Department of Sociology, Faculty of Arts and Human Science, University of Surrey, GU2 7XH, UK. Email: k.tyler@ surrey.ac.uk

\section{References}

American Anthropological Association 2004. 'American Anthropological Association Statement on "Race".' Pp. 97-100 in Mixed-race Studies: A Reader, edited by Jayne O. Ifekwunigwe. London, UK: Routledge.

Barker, Martin 1981. The New Racism: Conservatives and the Ideology of the Tribe. London, UK: Junction Books. Bodmer, Walter and McKie, R. 1995. The Book of Man. The Quest to Discover Our Genetic

Heritage. London, UK: Abacus Books. British Broadcasting Corporation, BBC 2. 2003. Motherland: A Genetic Journey, 14 February. Brodwin, Paul 2004. 'Genetics, Identity and the Anthropology of Essentialism.' Pp. 116-22 in Mixed Race Studies: A Reader, edited by Jayne O. Ifekwunigwe. London, UK: Routledge. Bulmer, Martin and John Solomos (eds) 1999. Racism. Oxford, UK: Oxford University Press. Carsten, Janet (ed.) 2000. Cultures of Relatedness: New Approaches to the Study of Kinship.

Cambridge, UK: Cambridge University Press.

Clarke, Morgan 2008. 'New Kinship, Islam, and the Liberal Tradition: Sexual Morality and New Reproductive Technology in Lebanon.' Journal of the Royal Anthropological Institute 14: 153-70.

Conduit, Michele, R. Parrott and T. Harris 2002. 'Lay Understandings of the Relationship Between Race and Genetics: Development of a Collectivized Knowledge Through Shared Discourse.' Public Understanding of Science 2: 373-87. Cooper, R. S., J. S. Kaufman and R. Ward 2003. 'Race and Genomics.' The New England Journal of Medicine 348: 1166-70. Cross, Kath 2001. 'Framing Whiteness: The Human Genome Diversity Project (As Seen on 
TV).' Science As Culture 10: 411-37. Duster, Troy 2002. 'Caught Between "Race" and a Hard Place.' Ethnicities 2: 547-54. Duster, Troy 2003. Backdoor to Eugenics (2nd edn). London, UK: Routledge.

Edwards, Jeanette 1999. 'Why Dolly Matters: Kinship, Culture and Cloning.' Ethnos 64: 301-24.

Edwards, Jeanette 2000. Born and Bred: Idioms of Kinship and the New Reproductive Technologies. Oxford, UK: Oxford University Press.

Edwards, Jeanette 2005. "Make-up": Personhood through the Lens of

Biotechnology.' Ethnos

70: 413-31. Edwards, Jeanette and Carles Salazar 2008. Kinship Matters: European

Cultures of Kinship in the Age of Biotechnology. Oxford, UK: Berghahn.

Edwards, Jeanette, Sarah Franklin, Eric Hirsch, Frances Price and Marilyn Strathern 1999. Technologies of Procreation: Kinship in the Age of Assisted Conception (2nd edn). Manchester, UK: Manchester University Press.

Franklin, Sarah 1997. Embodied Progress: A Cultural Account of Assisted Conception. London, UK: Routledge.

Franklin, Sarah and Margaret Lock (eds) 2003. Remaking Life and Death: Toward an Anthropology of the Biosciences. Oxford, UK: James Currey.

Franklin, Sarah and Susan Mckinnon (eds) 2001. Relative Values: Reconfiguring

Kinship Studies. Durham, NC: Duke University Press.

Gannett, L. 2001. 'Racism and Human Genome Diversity Research: The Ethical

Limits of Population Thinking.' Philosophy of Science 68: 479-92.

Gates, Henry Louis Jr. and Evelyn Brooks Higginbotham (eds) 2004. African

American Lives. Oxford, UK: Oxford University Press.

Gatson, S. N. 2003. 'On Being Amorphous: Autoethnography, Genealogy, and a

Multiracial Identity.' Qualitative Inquiry 9: 20-48.

Gilroy, Paul 1987. There Ain't No Black in the Union Jack. London, UK: Routledge.

Gilroy, Paul 1997. 'Diaspora and the Detours of Identity.' Pp. 299-346 in Identity and

Difference, edited by Kathryn Woodward. London, UK: Sage.

Gilroy, Paul 2000. Between Camps: Nations, Cultures, and the Allure of Race.

London, UK: Penguin Books.

Goldberg, David 1993. Racist Culture: Philosophy and the Politics of Meaning.

Oxford, UK: Blackwell Publishing.

Goldberg, David 1999. 'The Semantics of Race.' Pp. 362-77 in Racism, edited by

Martin Bulmer and John Solomos. Oxford, UK: Oxford University Press.

Haley, Alex 1976. Roots: The Saga of an American Family. New York, NY:

Doubleday.

Hall, Jacquelyn Dowd 1998. " "You Must Remember This": Autobiography as Social

Critique.' Journal of American History 85: 439-56.

Hall, Stuart 2003. 'Cultural Identity and Diaspora.' Pp. 233-46 in Theorizing

Diaspora, edited by Jana Evans Braziel and Anita Mannur. Oxford, UK: Blackwell

Publishing.

Hartouni, Valerie 1997. Cultural Conceptions: On Reproductive Technologies and the Remaking of Life. Minneapolis, MN: University of Minnesota Press.

Hayden, Corinne P. 1995. 'Gender, Genetics and Generation: Reformulating Biology

in Lesbian Kinship.' Cultural Anthropology 10: 41-63.

Horizon 1994. Sir Walter's Journey. BBC Television, 23 March.

Howell, Signe and Diana Marre 2006. 'To Kin a Transnationally Adopted Child in

Norway and Spain: The Achievement of Resemblances and Belonging.' Ethnos 71:

293-316. 
Inhorn, Marcia 2003. Local Babies, Global Science: Gender, Religion, and In Vitro Fertilization in Egypt. New York, NY: Routledge.

Kahn, Susan 2000. Reproducing Jews: A Cultural Account of Assisted Conception in Israel. Durham, NC: Duke University Press.

Kay, John 2002. 'White Couple Have Black IVF Twins: Shocking NHS Test Tube Bungle.' The Sun, 8 July.

Kay, L. E. 1993. The Molecular Vision of Life. Oxford, UK: Oxford University Press. Leake, Jonathan 2007. 'DNA Pioneer James Watson is Blacker Than He Thought.'

The Sunday

Times, 9 December. Lowe, Alex, L., Andrew Urquhart, Lindsay A. Foreman and Ian. W. Evett 2001. 'Inferring Ethnic Origin by Means of an STR Profile.' Forensic Science International 119: 17-22. Malik, Kenan 1996. The Meaning of Race: Race, History and Culture in Western Society. London, UK: Macmillan.

Nash, Catherine 2002. 'Genealogical Identities.' Environment and Planning D:

Society and Space

20: 27-52. Nash, Catherine 2004. 'Genetic Kinship.' Cultural Studies 18: 1-33. Nelkin, Dorothy and Susan Lindee 1995. The DNA Mystique: The Gene as Cultural Icon. New

York, NY: W. H. Freeman.

Parham, Angel Adams 2008. 'Race Memory and Family History.' Social Identities 14: 13-32.

Parker, David and Miri Song 2001. 'Introduction: Rethinking "Mixed Race".' Pp. 141 in Rethinking 'Mixed Race', edited by David Parker and Miri Song. London, UK: Pluto Press.

Ragoné, Heléna 1994. Surrogate Motherhood: Conception in the Heart. Boulder, CO: Westview Press.

Ragoné, Heléna 1998. 'Incontestable Motivations.' Pp. 118-31 in Reproducing Reproduction: Kinship, Power, and Technological Innovation, edited by Sarah Franklin and Heléna Ragoné. Philadelphia, PA: University of Pennsylvania Press. Ragoné, Heléna 2000. 'Of Likeness and Difference: How Race is Being Transfigured by Gestational Surrogacy.' Pp. 56-75 in Ideologies and Technologies of Motherhood: Race, Class, Sexuality, Nationalism, edited by Heléna Ragoné and France Winddance Twine. London, UK: Routledge.

Ragoné, Heléna and France Winddance Twine (eds) 2000. Ideologies and Technologies of Motherhood: Race, Class, Sexuality, Nationalism. London, UK: Routledge. Reardon, Jane 2001. 'The Human genome Diversity Project: A Case Study in Coproduction.' Social Studies of Science 31: 357-88. Rothman, B. Katz 1998. Genetic Maps and Human Imaginations: The Limits of Science in Understanding Who We Are. New York, NY: W. W. Norton. Schneider, David 1980. American Kinship: A Cultural Account (2nd edn). Chicago, IL: University of Chicago Press. Shiver, Mark D., Michael W. Smith, Li Jin, Amy Marcini, Joshua M. Akey et al. 1997. 'EthnicAffiliation Estimation by Use of Population-Specific DNA.' American Journal of Human Genetics

60: $957-64$.

Simpson, Bob 2004. 'Actually Ethically, Responding Culturally: Framing the New Reproductive and Genetic Technologies in Sri Lanka.' The Asia Pacific Journal of Anthropology 5: 227-43.

Skinner, David 2006. 'Racialized Futures: Biologism and the Changing Politics of Identity.' Social Studies of Science 36: 459-88. 
Skinner, David 2007. 'Groundhog Day? The Strange Case of Sociology, Race and “Science".' Sociology 41: 931-44.

Snowden, Robert and Elizabeth M. Snowden 1993. The Gift of a Child. Exeter, UK: University of Exeter Press.

Steinberg, Deborah L. 2000. 'Reading Genes/Writing Nation: Reith, "Race" and the Writings of Geneticist Steve Jones.' Pp. 173-98 in Hybridity and its Discontents:

Politics, Science, Culture, edited by Avtar Brah and Annie E. Coombes. London, UK: Routledge.

Strathern, Marilyn 1992. Reproducing the Future: Anthropology, Kinship and the New Reproductive Technologies. Manchester, UK: Manchester University Press. Strathern, Marilyn 2005. Kinship, Law and the Unexpected: Relative Are Always a Surprise. Cambridge, UK: Cambridge University Press.

Sykes, Bryan 2001. The Seven Daughters of Eve: The Astonishing Story that Reveals How Each of Us Can Trace Our Genetic Ancestors. London, UK: Bantam Books. Sykes, Bryan and C. Irven 2000. 'Surnames and the Y Chromosome.' The American Journal of Human Genetics 66: 1417-9.

Thompson, Charis 2001. 'Strategic Naturalising: Kinship in an Infertility Clinic.' Pp. 148-75 in Relative Values: Reconfiguring Kinship Studies, edited by Sarah Franklin and Susan Mckinnon. Durham, NC: Duke University Press.

Tutton, Richard 2002. 'Gift Relationships in Genetic Research.' Science as Culture 11: 523-42. Tutton, Richard 2004. " "They Want to Know Where They Came From": Population Genetics, Identity, and Family Genealogy.' New Genetics and Society 23: 105-20. Tyler, Katharine 2005. 'The Genealogical Imagination: The Inheritance of Interracial Identities.' The Sociological Review 53: 476-94.

Tyler, Katharine 2007. 'Race, Genetics and Inheritance: Reflections Upon the Birth of "Black" Twins to a "White" IVF Mother.' Pp. 33-51 in Race, Ethnicity and Nation:

Perspectives from Kinship and Genetics, edited by Peter Wade. Oxford, UK:

Berghahn.

Tyler, Katharine forthcoming. 'Whiteness Studies and Laypeople's Engagements with Race and Genetics.' New Genetics and Society.

Wade, Peter (ed.) 2007a. Race, Ethnicity and Nation: Perspectives from Kinship and Genetics. Oxford, UK: Berghahn.

Wade, Peter 2002. Race, Nature and Culture: An Anthropological Perspective. London, UK: Pluto Press.

Wade, Peter 2007b. 'Race, Ethnicity and Nation: Perspectives from Kinship and Genetics.' Pp. 1-31 in Race, Ethnicity and Nation: Perspectives from Kinship and Genetics, edited by Peter Wade. Oxford, UK: Berghahn.

Waters, M. 1990. Ethnic Options: Choosing Identities in America. Berkeley, CA: University of California Press.

Weston, Kath 1991. Families We Choose: Lesbians, Gays, Kinship. New York, NY: Columbia University Press.

Wetherell, Margaret and Jonathan Potter 1992. Mapping the Language of Racism: Discourse and the Legitimation of Power. London, UK: Harvester Wheatseaf.

Wiegman, Robyn 2003. 'Intimate Publics: Race, Property, and Personhood.' Pp. 296320 in Race, Nature and the Politics of Difference, edited by Donald S. Moore, Jake Kosek and Anand Pandian. Durham, NC: Duke University Press. 